\title{
Methodological support of training future engineers based on media technologies
}

\author{
Madina GANIHANOVA ${ }^{1}$ \\ Tashkent State Technical University named after Islam Karimov
}

\begin{tabular}{l} 
ARTICLE INFO \\
\hline Article history: \\
Received October 2021 \\
Received in revised form \\
15 October 2021 \\
Accepted 20 November 2021 \\
Available online \\
15 December 2021 \\
\\
\hline Keywords: \\
pedagogical technologies, \\
communicative teaching, \\
Multimedia, \\
information, \\
Media education, \\
pedagogical level.
\end{tabular}

\begin{abstract}
In this article, the method based on exercises is considered, since in the learning process almost everything depends on the methodicality and inclusion of the learner in the learning process. With the communicative method of teaching, all exercises should be of a speech nature, that is, mutually communicative exercises. There are two series of exercises: conditional speech and applied speech. Conditional speech exercises are exercises specially organized for the formation of professional skills.
\end{abstract}

2181-1415/C 2021 in Science LLC.

DOI: https://doi.org/10.47689/2181-1415-vol2-iss11/S-pp215-219

This is an open access article under the Attribution 4.0 International (CC BY 4.0) license (https://creativecommons.org/licenses/by/4.0/deed.ru)

\section{Mediatexnologiyalar asosida bo'lajak muhandislarni tayyorlash metodologiyasi}

\author{
Kalit so'zlar: \\ pedagogik texnologiyalar, \\ kommunikativ o'qitish, \\ multimedia, \\ axborot, \\ mediata'lim, \\ pedagogik daraja.
}

\begin{abstract}
ANNOTATSIYA
$\mathrm{Bu}$ usul mashqlarga asoslangan, chunki o'quv jarayonida deyarli hamma narsa mashqlarga bog'liq. O'qitishning kommunikativ usulida barcha mashqlar tabiatda nutqqa qaratilgan bo'lishi kerak, ya'ni muloqot mashqlari. 2 ta mashq turkumi mavjud: shartli nutq va nutq. Shartli nutq mashqlari malakani shakllantirish uchun maxsus tashkil etilgan mashqlardir.
\end{abstract}

\footnotetext{
1 Teacher of the Foreign Languages Department, Named after Islam Karimov Tashkent State Technical University. Tashkent, Uzbekistan. E-mail: mbganikhanova@gmail.com.
} 


\section{Методическое обеспечение подготовки будущих инженеров на основе медиа-технологий}

\author{
Ключевые слова: \\ педагогические \\ технологии, \\ коммуникативное \\ обучение, \\ мультимедиа, \\ информация, \\ медиаобразование, \\ педагогический уровень.
}

\begin{abstract}
АННОТАЦИЯ
В данной статье, рассмотрен, метод основанный на упражнениях, так как в процессе обучения практически все зависит от методичности и включения обучаемого в процесс обучения. При коммуникативном методе обучения, все упражнения должны носить речевой характер, то есть, взаимно коммуникативные упражнения. Есть, две серии упражнений: условная речь и применительная речь. Условно-речевые упражнения - это упражнения, специально организованные для формирования профессиональных навыков.
\end{abstract}

\section{INTRODUCTION}

In order to realize truly communicative teaching of communication, you need to take care, first of all, that the tasks offered to the students are, in fact, speech-and-thinking tasks.

Active learning is such an organization and conduct of the educational process, which is aimed at the all-round activation of the educational and cognitive activity of students through a wide, preferably integrated, use of both pedagogical (didactic) and organizational and managerial means.

The activation of training can go both through the improvement of forms and methods of training, and along the path of improving the organization and management of the educational process or the state education system. The condition for achieving serious positive results is considered to be active participation in the process of activating both teaching and responsible state structures, that is, all subjects of the educational process, and the widest possible use of various means and methods of activation by them.

\section{MATERIALS AND METHODS}

The ideas of enhancing education were expressed by scientists throughout the entire period of formation and development of pedagogy long before it was formalized into an independent scientific discipline. The founders of the ideas of activation include Ya.A. Komensky, J.-J. Rousseau, I.G. Pestalozzi, G. Hegel, F. Froebel, A. Disterweg, J. Dewey, K.D. Ushinsky and others. However, the ideas that received the most consistent presentation in the works of these authors originate from the statements of scientists and thinkers of the ancient world.

The didactic prerequisites include pedagogical technologies, to one degree or another, realizing and developing certain principles of active learning:

1. Problem-based learning develops an approach to enhancing the creative activity of students through the presentation of problem-formulated tasks. The theory also contains a provision on teaching students to solve problematic problems, but reveals it on the basis of traditional methods.

2. Programmed learning has made a significant contribution to the development of approaches to the individualization of learning based on specially constructed training courses for individual use, which received a new impetus for development in connection with the development of computer technologies and the emergence of distance learning. 
3. Contextual learning is based on the position of the theory of activity, according to which, the assimilation of social experience is carried out as a result of active, "biased" activity of the subject. The following principles are embodied in it: personality activity; problematic; the unity of training and education; sequential modeling in the forms of educational activity of students of the content and conditions of professional activity of specialists. As a means of implementing the theoretical approach in contextual learning, it is proposed to fully use the methods of active learning.

4. Game learning has proven the high efficiency of using game, competitive, team teaching methods [5. P. 43].

The problem-based teaching method is based on the theoretical positions of the American philosopher, psychologist and teacher J. Dewey (1859-1952), who founded an experimental school in 1894 in Chicago, in which the curriculum was replaced by play and work.

Conceptual provisions by J. Dewey:

The problem-based teaching method is an active method, which is distinguished by the principle of problematicity, which involves the use of the objective inconsistency of the studies and the organization of the search for new knowledge, methods and techniques for solving problems. The didactic unit of the method is a problem.

Problem-based learning is based on the creation of a special type of problem motivation, therefore, it requires an adequate construction of the didactic content of the material, which should be presented as a chain of problem situations.

In the modern theory of the problem-based teaching method, two types of problem situations are distinguished: technical and pedagogical. The first concerns the activities of students, the second represents the organization of the educational process.

Computer learning is based on programs and a well-developed teaching method. The essence of the programmed teaching method is that all teaching is not conducted by the teacher directly, it is carried out on the basis of teaching programs implemented in two versions: machineless (programmed textbooks, sets of cards, punched cards, etc.) and machine (mainly using a computer). Computer training software includes systems and training programs. Computer training carries a huge amount of motivational material, and motivation is of great importance in teaching foreign languages.

The main goals of computer training are:

- formation of skills to work with information, development of communication skills;

- preparation of the personality of the "information society";

- formation of research skills;

- formation of skills to make optimal decisions;

- present as much information as the student is able to assimilate.

The conceptual features of the application of computer learning are:

- the principle of adaptability: adaptation of the computer to the individual characteristics of each student;

- controllability: at any time the teacher can correct the learning process;

- unlimited learning: the content, its interpretation and applications can be as large as you like;

- maintaining the student's psychological comfort when communicating with the computer;

- interaction of a student with a computer can be carried out in all types: subject subject, subject - object, object - subject. 
Currently, the following groups of programs are distinguished:

- training programs for individual work at home or in computer classes, focused on mastering grammatical forms, lexical units and individual speech patterns, as well as programs for teaching reading and writing, involving the use of a text editor;

- text programs for individual, pair and group work, allowing you to modify the text: to place punctuation marks, rearrange sentences, edit text, etc.;

- game programs based on problem situations and contributing to the motivation of students;

- test programs that allow for various types of testing;

- databases and programs developed on their basis.

The first group of programs represents techniques known in the technique, for example, restoration. The creators of these programs strive to make them interactive, i.e. provide for the active participation of trainees in the performance of tasks.

The programs of the second group are more focused on the content side of education. The most common of these is the StoryBoard program. The program is based on the recovery technique, when a short text appears on the screen, in which the punctuation marks and the name are saved, and dashes are left instead of words. The task of the students is to recover the text. The program also provides modes that allow students to adjust the degree of difficulty of the exercises performed, that is, decide in which sequence to skip words, use keys or not, etc.

The third group of programs is all kinds of games that are widely known and popular among children and adults.

Test programs are intended mainly for final control, marking and determining the level of language proficiency of students. These programs can also be educational, as they involve the independent preparation of students for exams. They are provided with keys and instructions to help students with independent work.

Among the programs of the fifth group, you can name programs that allow you to find out the derivatives of a word, the compatibility of the search word, its frequency, and also introduce you to the use of a particular word in a broader context.

Conclusion: Teaching using a computer develops the idea of a programmed teaching method, opens up completely new, not yet explored technological options for teaching associated with the unique capabilities of modern computers and telecommunications. Learning with the use of a computer is the process of preparing and transmitting information to a trainee, the means of which is a computer.

Many scientists involved in teaching foreign languages have rightly paid attention to the effectiveness of using the game method. This is due to the fact that in the game, the abilities of any person, and of a child in particular, are manifested especially fully, and sometimes unexpectedly.

\section{REFERENCES:}

1. Усов Ю.Н. Медиаобразование. Программа для студентов 10-11 класса общеобразовательной школы // Основы экранной культуры. Цикл программ / Рук. Ю.Н. Усов. - М., 1998.

2. Уэллс У. и др. Реклама: принципы и практика. - СПб.: Питер, 2001. - С. 800.

3. Фатеева И.А. Медиаобразование: теоретические основы и опыт реализации. - Челябинск: Изд-го Челяб.гос.ун-та, 2007. - С. 270. 
4. Федоров А.В. Развитие медиакомпетентности и критического мышления студентов педагогических вузов. М.: 2007. - С. 615.

5. Федоров А.В. Бўлажак мутахассисларга медиатаълим бериш. Таганрог, 2005. - Б. 83-85.

6. Федоров А.В. Медиаобразование: вчера и сегодня. - М.: Изд-во МОО ВПП ЮНЕСКО “Информация для всех", 2009. - С. 234.

7. Феофанов О.А. Реклама: новые технологии в России. СПб.: Питер, 2001. - С. 384. 